\title{
Chapter 8 \\ Commentary: A Spatial Planning \\ Perspective on Privately Funded Natural \\ Water Retention Measures
}

\author{
Lukas Löschner
}

This contribution puts privately funded natural water retention measures (NWRM) in a spatial planning perspective. It comments on the case presented by Slavíková and Raška (this volume), which investigates the role of a forest engineer and farmer (Mr. Pitek) who acquired and restored degraded agricultural areas by improving the water retention capacities and developing more sustainable farming practices. The case is exceptional because it illustrates that private initiatives may actually support, and not only undermine, public policy goals concerning the enhancement of biodiversity and landscape ecology. It thus stands in contrast to related studies, which typically explore the efforts of public authorities and their respective policy instruments to implement NWRM. Such studies often identify private landowners as a key target group of policy interventions (due to their private rights to property and land use), but focus on the policy means by which to incentivise NWRM or mobilise land to facilitate their realisation. Instead of placing private landowners at the receiving end of environmental policies, this study provides a bottom-up landowner perspective. It investigates the personal motivations for restoring the ecological quality of landscapes and provides valuable insights into the (mal)functioning of specific policy instruments (e.g., agricultural subsidies) and the bureaucratic procedures involved in landscape restoration.

Although Mr. Pitek's initiative to restore water retention ponds is principally in line with the overall aims of environmental policy in the region, he makes a point "to do what he considers to be the right thing without subordinance to public authorities and/or subsidy schemes" (Slavíková and Raška, this volume). He has purposely chosen to build a series of small retention pools "to avoid complicated permitting processes related to changes in land use designation". In fact, Mr. Pitek's plans to install larger ponds remain to be realized due to lengthy authorization processes and

L. Löschner $(\bowtie)$

Department of Landscape, Spatial and Infrastructure Sciences, Institute of Spatial Planning, Environmental Planning and Land Rearrangement (IRUB), University of Natural Resources and Life Sciences Vienna (BOKU), Vienna, Austria

e-mail: lukas.loeschner@boku.ac.at

T. Hartmann et al. (eds.), Nature-Based Flood Risk Management on Private Land, https://doi.org/10.1007/978-3-030-23842-1_8 
he "seems to be frustrated with this bureaucracy". He is moreover highly sceptical of agricultural subsidies, which he criticizes for "sending perverse incentives to land management and agricultural production"; "instead of supporting measures, such as those aimed at water retention and biodiversity (...) subsidies [are provided] to intensive production of crops for biofuels".

Mr. Pitek's satisfaction "with the possibility to restore pools on his own-cheaply and fast" illustrates that the prevailing set of regulatory and financial instruments in Czech environmental policy is apparently not suited to foster NWRM on privately owned land. While the effectiveness of agricultural subsidies and regulations is a critical issue in this regard, the aim of this contribution is to place the above case in a spatial planning perspective. In this vein, it provides a reflection on the opportunities and limitations of spatial and land policy instruments to implement NWRM and discusses the contribution of this study for related research in environmental policy.

\section{Securing Land Resources for NWRM with Spatial Planning Instruments}

Generally speaking, spatial planning refers to "the geographical expression, implementation, and coordination of public policy across sectors and scales. (...) By creating spatial plans [it] expresses where and in what form policy will unfold, coordinates and aligns initiatives to avoid duplication of effort or divergent policies being adopted" (Castree et al. 2013, p. 485). Regulatory instruments of spatial planning-for example, regional spatial plans, local zoning plans or building schemes-can thus play an important role to legally secure the necessary land resources for NWRM. Regional spatial plans, for instance, may be used to designate large-scale areas for flood retention or flood runoff (see Löschner et al., this volume). Similarly, regional spatial plans may be used to preserve wetlands and natural floodplain, not only as a means to attenuate runoff attenuation and propagate flood waves, but mainly to preserve and enhance the biodiversity of riverine ecosystems. Local zoning plans are also effective formal planning instruments to allocate land for green and blue infrastructure, while building schemes may, for instance, be used to define smallscale rainwater detention basins on the plot-level and thus contribute towards better municipal rainwater management in the face of climate-induced increases in pluvial floods.

These (formal) spatial planning instruments are, however, overwhelmingly limited to settlement areas and building land. In general, spatial planning has little leverage on agricultural or forestry land. Apart from assessing the compatibility of land use plans, spatial planning does not dispose of the necessary regulatory means to infringe on agricultural land and is therefore not able to play a significant role in facilitating NWRM in these areas. 


\section{Mobilising Land Resources for NWRM Through Land Consolidation}

Given these limitations, it may be useful to also consider instruments of land policy (as a closely related discipline) and take a look in particular at the instrument of land consolidation and its possibilities to realize public aims on privately-owned agricultural and forest land. Land consolidation is an instrument of land management to enlarge, redesign, rearrange and improve agricultural and forest land. As indicated, for instance, in the Austrian federal Framework Land Consolidation Act, the objective of land consolidation is to improve and rearrange the conditions of agricultural cultivation on behalf of an efficient and environmentally friendly agriculture by consolidation and development of agricultural and forest land (Mansberger and Seher 2017). Land consolidation schemes generally demand a bottom-up initiative and a common interest on the side of the landowner(s) to rearrange parcels of agricultural land for a certain benefit. A land consolidation scheme may thus be started if disadvantages in farming structure (land fragmentation of unfavourable plot size) shall be eliminated.

Although the core task of land consolidation is the improvement of farming structures, in Austria the instrument is also applied to obtain the necessary land resources for the public benefit, such as the development of traffic infrastructure. In this vein, multifunctional land consolidation schemes are also increasingly implemented to address non-agricultural, land-related issues, such as acquiring land for flood retention and flood protection measures, as well as for river restoration and nature conservation. Land acquisition for flood plains, considering both public interests and landowners' expectations can be realised by means of land consolidation. The substantial strength of this procedure lies within the mobility of land, as parcels may be purchased anywhere within the consolidation area and allocated where needed. This allows, for instance, for the creation of coherent areas for flood runoff and flood retention, which would normally not be possible through land acquisition, given the oftentimes large number of riparian landowners. Nevertheless, multifunctional land consolidation is strongly dependent on the availability of land required by planning authorities. In the future, restrictions for this type of land consolidation can be expected due to increasing agricultural land use demands as a result of higher prices for agricultural products and the production of renewables (Seher 2015).

\section{Further Questions and Lessons Learned}

The above spatial planning and land policy instruments are of course only applicable if a need to provide (private) land for a specific environmental policy goal exists, such as natural water or flood retention. In the case of Mr. Pitek, however, agricultural practices actually align with and in many ways support public aims to increase biodiversity and water retention capacities in degraded agricultural areas. 
The principal question concerning this case therefore is not how we may secure or mobilise the necessary land resources to better fulfil a public policy aim, but rather how comparable initiatives by private landowners may be promoted.

In this regard, Slavíková and Raška rightly stress that the current agricultural subsidy scheme is too fixated on agricultural production and is therefore in need of reconsideration to also provide incentives for multifunctional land uses and more locally attuned cultivation methods. They, however, also highlight the central role of land ownership_-in particular given Czechia's rather recent transition to a market economy-to effectively implement NWRM: to Mr. Pitek, "the only way forward (...) was to become a landowner and to undertake changes on his own property". Owning the land allows him to get things done "fast and cheap (although nonparticipatory and to some extent non-expert)". This puts planning authorities into a bit of a dilemma because it shows the difficulties of involving such hidden champions in a more coordinated environmental policy scheme. Although Mr. Pitek's agricultural approach has drawn increasing scholarly attention and shows apparent benefits in terms of an observed increase in biodiversity as well as agricultural yield, "no permanent monitoring" to assess the actual hydrological effects and ancillary benefits of his actions has been put into place.

With the aim of bringing private initiatives and public authorities together, a big challenge therefore appears to be to build a better understanding of the different rationales but maybe also how to build mutual trust. Slavíková and Raška mention that efforts have been made to promote "participatory governance schemes" in this field. Especially in a former Communist country with a weak tradition in participatory planning approaches, it would be interesting to learn more about these governance schemes and processes: What are their specific aims? How are they organised? Who is involved and why is it so challenging to get people "on board"? Which role could people like Mr. Pitek play in such processes? Delving deeper into these issue could provide further insights into how private initiatives and public aims in environmental policy can be more clearly aligned.

Overall, the account of Mr. Pitek, however, is highly valuable because it gives a rare stakeholder-centred perspective on environmental policy. It shows that research can benefit from zooming in on a landowner perspective to obtain complementary insights to the often policy-centred research. Apart from learning about the farmers' intrinsic motivations, the case also provides interesting insights into different policy instruments. It thus highlights that-when investigating policy instruments (be they in spatial planning, land policy or agriculture)—it is critical to not just look at "how intentions of policy are translated into operational activities" (de Bruijn and Hufen 1998, p. 12) but to also account for those targeted by the policy instruments. Such a perspective may help understand in how far subsidies, regulations or other policy instruments are able to achieve their desired effect (e.g., by delivering changes in land use and fostering NWRM). At the same time it is crucial to keep in mind that policy instruments are generally not simply functional in design, but instrument choice actually depends on a number of different factors, including the institutional context, interest groups etc. (Linder and Peters 1989). Bringing the 
different perspectives - stakeholder-policy and substantive-process - in the research on policy instruments together can contribute to developing a more encompassing understanding of environmental policies.

Acknowledgements Open access of this chapter is funded by COST Action No. CA16209 Natural flood retention on private land, LAND4FLOOD (www.land4flood.eu), supported by COST (European Cooperation in Science and Technology).

\section{References}

Castree N, Kitchin R, Rogers A (2013) A dictionary of human geography. Oxford University Press, Oxford

de Bruijn H, Hufen H (1998) The traditional approach to policy instruments. In: Peters BG, van Nispen FKM (eds) Public policy instruments: evaluating the tools of public administration. Edward Elgar Publishing, Cheltenham, pp 11-32

Linder SH, Peters BG (1989) Instruments of government: perceptions and contexts. J Publ Policy 9(1):35-58. https://doi.org/10.1017/S0143814X00007960

Mansberger R, Seher W (2017) Land administration and land consolidation as part of Austrian land management. EU Agrarian Law 6(2):68-76. https://doi.org/10.1515/eual-2017-0010

Seher W (2015) Potenziale der Grundzusammenlegung als Instrument des Flächenmanagements in ländlichen Räumen Österreichs. Zeitschrift für Verwaltung (ZfV) 6:365-372. https://doi.org/10. 12902/zfv-0082-2015

Dr. Lukas Löschner has an academic background in Political Science and Landscape Planning and holds a Ph.D. in Spatial Planning. His main field of research is natural hazard risk management, which he explores in a combination of political science and planning approaches. He currently conducts research on the following topics: spatial adaptation to flooding, policy coordination in FRM, flood risk governance, and flood storage compensation.

Open Access This chapter is licensed under the terms of the Creative Commons Attribution 4.0 International License (http://creativecommons.org/licenses/by/4.0/), which permits use, sharing, adaptation, distribution and reproduction in any medium or format, as long as you give appropriate credit to the original author(s) and the source, provide a link to the Creative Commons license and indicate if changes were made.

The images or other third party material in this chapter are included in the chapter's Creative Commons license, unless indicated otherwise in a credit line to the material. If material is not included in the chapter's Creative Commons license and your intended use is not permitted by statutory regulation or exceeds the permitted use, you will need to obtain permission directly from the copyright holder. 